\title{
PENGARUH HARI PERDAGANGAN TERHADAP RETURN SAHAM (PENGUJIAN THE DAY OF THE WEEK, WEEK-FOUR EFFECT DAN ROGALSKI EFFECT) PADA PERUSAHAAN KEUANGAN DI BURSA EFEK INDONESIA PERIODE 2017
}

\author{
Rizki Khoiri \\ khoiririzki1310@gmail.com \\ Universitas Ahmad Dahlan \\ Deny Ismanto \\ denoxis@yahoo.com \\ Universitas Ahmad Dahlan
}

\begin{abstract}
ABSTRAK
This study aims to examine (1) the difference in average daily return in one week (2) test the occurrence of negative returns on the fourth and fifth weeks of Monday on financial sector stock returns on the Indonesia Stock Exchange in the period 2017 and (3) test whether a positive return and tends to be larger than other months on Monday in April. The population in this study were financial sector companies listed on the Indonesia Stock Exchange. Samples were taken by purposive sampling method. Samples consisted of 6 financial sector companies listed on the Indonesia Stock Exchange and included in LQ45 during the 2017 period. The results of data analysis show that trading days have no significant effect on stock returns. There is no negative return on the fourth and fifth week of Monday on stock returns and positive returns are found and tend to be greater than the other months on Monday in April on financial sector stock returns on the Indonesia Stock Exchange in the 2017 period.
\end{abstract}

Keywords: Effect of Trading Day Against Stock Returns; The Day Of The Week Effect; WeekFour Effect; Rogalski Effect.

\section{PENDAHULUAN}

Pasar modal merupakan salah satu alternatif investor yang dapat dipilih dalam melakukan investasi. Pasar modal mempunyai peran strategis bagi perusahaan sebagai salah satu sumber pembiayaan. Menurut UU No.8 Th. 1995 pasar modal adalah kegiatan yang bersangkutan dengan penawaran umum dan perdagangan efek, perusahaan publik yang berkaitan dengan efek yang diterbitkannya, lembaga dan profesi yang berkaitan dengan efek.

Sebagai investor sebelum melakukan transaksi di pasar modal, investor sangat membutuhkan informasi untuk mengambil keputusan dalam memilih sekuritas. Investor ingin mendapatkan berbagai informasi yang akurat secara terbuka maupun secara tertutup. Informasi yang baru akan membuat investor berpikir ulang dalam melakukan transaksi, karena bisa membuat pasar menjadi overadjusted atau underadjusted. Jika semakin cepat reaksi pasar terhadap informasi yang dipublikasikan, maka pasar tersebut dapat dikatakan pasar modal efisien.

Menurut Tandelilin (2010) pasar yang efisien adalah pasar dimana semua sekuritas yang diperdagangkan telah mencerminkan semua informasi yang tersedia, baik informasi dimasa lalu (laba perusahaan tahun lalu), informasi saat ini (misalnya rencana kenaikan deviden tahun ini), maupun informasi yang bersifat pendapat atau opini rasional yang beredar di pasar yang bisa mempengaruhi perubahan harga (misalnya jika banyak 
investor di pasar berpendapat bahwa harga saham akan naik, maka informasi tersebut nantinya akan tercermin pada perubahan harga saham yang cenderung naik).

Gumanti (2011) menyatakan bahwa hipotesis pasar efisien atau Efficient Market Hypothesis merupakan salah satu terobosan yang menarik dalam perkembangan teori keuangan. Efisiensi pasar atau hipotesis pasar efisien (efficiency market hypothesis) pertama kali dikemukakan oleh Fama pada tahun 1970. Menurut Fama (1970) dalam Tandelilin (2001) ada tiga tingkatan yang berbeda dari efisiensi pasar. Tiga tingkat efisiensi tersebut adalah efisiensi pasar bentuk lemah (weak strong), efisiensi pasar bentuk semi kuat (semistrong form), efisiensi pasar bentuk kuat (strong form). Tiga tingkatan ini membutuhkan informasi yang berbeda-beda. Efisiensi pasar bentuk lemah membutuhkan informasi yang sudah terjadi atau informasi masa lalu. Efisiensi pasar bentuk setengah kuat membutuhkan semua informasi yang dipublikasikan. Sedangkan efisisensi pasar bentuk kuat membutuhkan semua informasi yang tersedia termasuk informasi yang privat.

Meski konsep hipotesis pasar efisien telah diterima dalam bidang keuangan, namun penyimpangan atau anomali akan tetap ada. Beberapa penelitian telah menunjukkan bahwa terdapat suatu anomali atau penyimpangan yang ada di pasar modal, yang mempunyai dampak cukup signifikan. Anomali yang sering terjadi di pasar modal dimaanfaatkan investor agar dapat memperoleh abnormal return.

Hartono (2003) mendefinisikan anomali pasar sebagai teknik atau strategi yang tampaknya bertentangan dengan pasar efisien.Anomali pasar dapat diketahui apabila pada saat waktu tertentu terdapat pembentukan dan pengulangan pola atau perubahan yang bisa diprediksi. Anomali pasar yang akan peneliti gunakan antara lain day of the week effect, weekfour effect, dan rogalski effect.
Pada teori pasar efisien menyatakan bahwa return saham setiap hari tidak memiliki perbedaan. Fenomena day of the week effect menyatakan bahwa pada masing-masing hari perdagangan dalam satu minggu terdapat perbedaan return.

Penelitian tentang day of the week telah banyak dilakukan. Gibbons dan Hess (1981) dalam Tandelilin (2010) menemukan bahwa return pada hari Senin akan lebih rendah dibandingkan dengan hari lain di Bursa Saham New York. Penelitian lainnya dilakukan oleh Harris (1986) dalam Tandelilin (2010) menemukan bahwa pada hari Senin terdapat return negatif, tetapi pada empat hari lainnya tidak memiliki return negatif. Penelitian lainnya dilakukan oleh Prayogo (2009) menemukan bahwa return saham JII pada hari senin lebih rendah dibandingkan hari selain senin. Rita (2009) hasilnya menemukan bahwa rata-rata return hari Senin paling rendah dibanding ratarata return pada hari selain Senin nilainya bahkan mencapai nilai negatif.

Sementara Widodo (2010) dan Arum Ambarwaty (2016) tidak menemukan adanya pengaruh hari perdagangan terhadap return saham.

Banyak penelitian yang telah mengungkapkan adanya return negatif pada hari perdagangan senin. Iramani (2006) mengungkap bahwa rata-rata return hari Senin pada akhir bulan adalah negatif signifikan sedangkan rata-rata return hari Senin pada awal bulan tidak signifikan atau tidak berbeda dengan nol. Dapat dikatakan bahwa Monday effect biasanya hanya terjadi pada minggu akhir bulan yaitu pada minggu keempat dan kelima. Fenomena tersebut disebut dengan sebutan week four effect. Hasil penelitian Cahyaningdyah (2005) tidak menemukan adanya Week Four Effect di BEJ tahun 2001-2003. Artinya tidak terjadinya week four effect di BEJ.

Tujuajn penelitian dalam artikel ini untuk menguji perbedaan return harian rata-rata dalam satu minggu pada 
return saham sektor keuangan di Bursa Efek Indonesia selama periode 2017, Untuk menguji terjadinya return negatif pada senin minggu keempat dan kelima pada return saham sektor keuangan di Bursa Efek Indonesia, Untuk menguji terjadinya return positif dan cenderung lebih besar dibandingkan bulan lainnya pada hari senin di bulan April

\section{REVIEW LITERATUR DAN HIPOTESIS}

\section{Pasar Modal}

Pasar modal merupakan sarana bertransaksi penjual dan pembeli menggunakan produk yang berupa surat berharga yang dikeluarkan oleh suatu perusahaan. Menurut Yuad Husnan dalam Prayogo (2009) pasar modal adalah pasar untuk berbagai instrumen keuangan atau sekuritas jangka panjang yang dapat diperjualbelikan, baik dalam bentuk hutang maupun modal sendiri, baik yang diterbitkan pemerintah, public autorities, maupun perusahaan swasta

\section{Efisiensi Pasar}

Pasar efisien adalah pasar yang mempunyai informasi yang akurat yang dapat dipercaya sebagai acuan pembelian. Pasar yang efisien adalah pasar dimana harga semua sekuritas yang diperdagangkan telah mencerminkan semua informasi yang tersedia (Tandelilin, 2001) mengevaluasi kinerja untuk menemukan kelemahan dan keunggulan perusahaan.

\section{Anomali Pasar Efisien}

Anomali pasar adalah teknik-teknik atau strategi-strategi yang berlawananatau bertentangan dengan konsep pasar modal yang efisien dan penyebab kejadian tersebut tidak dapat dijelaskan dengan mudah (Hartono, 2003). Anomali pasar berarti terdapat penyimpangan terhadap hipotesis kondisi pasar modal yang efisien yang berkaitan dengan pola return yang berantakan serta ketidakmampuan investor untuk mendapatkan return secara konsisten diatas rata-rata return pasar. Anomali tidak hanya muncul pada satu bentuk efisiensi pasar saja tetapi pada semua bentuk efisiensi pasar, baik efisiensi pasar bentuk kuat, semi kuat dan lemah.Anomali dapat dimanfaatkan para investor untuk mendapatkan abnormal return.

\section{Day of the Week Effect}

Day of the week effect merupakan anomali yang menyebabkan hari perdagangan mempengaruhi pola tingkat pengembalian saham (Trisnadi dan Sedana, 2016). Pada Day of the week effect terdapat perbedaan return yang signifikan antara hari Senin dengan harihari lainnya dalam seminggu. Return yang relatif paling rendah dan cenderung negatif terjadi pada hari Senin, sedangkan return positif terjadi pada hari-hari lainnya dalam seminggu.

Telah terdapat banyak studi yang dilakukan dan menghasilkan bukti empiris untuk mengungkap adanya return negatif pada hari senin. Salah satunya penelitian dari Cahyaningdyah (2005) menemukan bahwa hari Senin, Rabu, Kamis, dan Jumat mempunyai pengaruh terhadap return saham sementara hari Selasa tidak mempunyai pengaruh terhadap return saham. Kristiawan (2010) penelitian di BEI selama periode 2004-2006 menyimpulkan bahwa hari perdagangan berpengaruh terhadap return.

Banyak hal yang menyebabkan terjadinya pengaruh hari perdagangan.Salah satu penyebabnya ialah terdapatnya informasi yang tidak menyenangkan yang datang ke pasar setelah tutupnya perdagangan pada hari perdagangan jumat. Penyebab lainnya ialah psikologis investor itu sendiri. Psikologis investor yang tidak menyukai hari senin, relatif cenderung melakukan tindakan yang tidak rasional dalam melakukan transaksi. Hal ini akan membuat transaksi mendapatkan return yang cenderung rendah pada hari 
perdagangan senin dibandingkan dengan hari lainnya dalam seminggu.

\section{Week-Four Effect}

Week-four effect adalah suatu anomali yang menyatakan bahwa Monday Effect hanya terjadi pada minggu keempat dan kelima untuk setiap bulan. Sedangkan pada minggu pertama sampai minggu ketiga return pada hari senin tidak signifikan negatif. Menurut Rita (2009) Week Four Effect adalah rata-rata Senin yang negatif hanyaterjadi pada Senin minggu keempat dan kelima.

Iramani (2006) mengungkap bahwa rata-rata return hari Senin pada akhir bulan adalah negatif signifikan sedangkan ratarata return hari Senin pada awal bulan tidak signifikan atau tidak berbeda dengan nol. Dapat dikatakan bahwa Monday effect biasanya hanya terjadi pada minggu akhir bulan yaitu pada minggu keempat dan kelima.

Wang, et.al., (1997) dalam Rita (2009) mengungkapkan bahwa Monday effect secara aktual muncul hanya pada hari Senin minggu keempat dan kelima, sedangkan return Senin minggu pertama sampai ketiga secara statistik tidak menunjukkan perbedaan. Hal ini berarti bahwa return hari Senin negatif yang terbesar terjadi pada minggu keempat. Penelitian tersebut dilakukan terhadap indeks return saham (NYSE-AMEX, S\&P composite index, serta Nasdaq) dengan periode penelitian 1962-1993.

Hal ini biasanya disebabkan oleh kebutuhan dari para investor itu sendiri. Pada minggu keempat dan kelima pada setiap bulan dapat dikatakan adalah akhir bulan, dimana kebutuhan para investor cenderung meningkat tetapi penghasilan investor belum bertambah, hal ini terjadi dikarenakan biasanya perusahaan dan instansi membayar upah karyawan pada minggu pertama. Sehingga hal ini menyebabkan investor menjual saham mereka dibandingkan dengan melakukan transaksi pembeliam saham.

\section{Rogalski Effect}

Rogalski

Cahyaningdyah (2005) menemukan adanya hubungan yang menarik antara day of the week effect dengan january effect, dimana ditemukan bahwa rata-rata return negatif pada hari senin, menghilang pada bulan januari. Rogalski effect merupakan suatu fenomena dimana return negatif pada hari senin (Monday Effect) tidak terjadi pada bulan tertentu. Hal ini terjadi dikarenakan terdapatnya return yang lebih tinggi pada bulan tersebut dibandingkan pada bulan lainnya.

Menurut beberapa penelitian yang dilakukan di Indonesia Rogalski effect kemugkinan terjadi pada bulan April atau sering disebut april effect. Penelitian Cahyaningdyah (2005) menemukan fenomena Rogalski Effect pada pasar modal Indonesia dibulan April. Umi Murtini (2007) menemukan bahwa return hari senin bulan april adalah positif atau cenderung lebih tinggi dari return hari senin bulan lainnya.

Rogalsky effect dapat terjadi pada bulan april karena ketentuan yang ditetapkan oleh Badan Pengawas Pasar Modal No.80/PM/1996, yang menyatakan bahwa laporan tahunan harus disertai dengan laporan akuntan dengan pendapat yang lazim dan disampaikan kepada Bapepam 120 hari setelah tanggal tahun tutup buku perusahaan. Hal ini berarti bahwa laporan keuangan maksimum disampaikan pada bulan April (Hendi dan Darmadji, 2001). Oleh karena itu sebelum bulan April dan pada awal bulan April banyak perusahaan yang menyampaikan laporan keuangan tahunan

(Usman dan Riphat, 1997). Dengan menyerahkan laporan keuangan perusahaan menyebabkan pasar menganggap kinerja perusahaan ada pada keadaan yang cukup baik untuk masa yang akan datang. Sehingga pada bulan aprilreturn mengalami kecenderungan lebih tinggi dari pada bulanbulan lainnya. 


\section{Hipotesis}

H1: Terjadi perbedaan return harian ratarata dalam satu minggu pada return saham sektor keuangan (The Day of TheWeek Effect)

$\mathrm{H} 2$ : Terjadi return negatif pada senin minggu keempat dan kelima pada return saham sektor keuangan (Week Four Effect)

H3 : Terjadi return positif dan cenderung lebih besar dibandingkan bulan lainnya pada hari senin di bulan April (Rogalski Effect)

\section{METODE PENELITIAN}

\section{Populasi dan Sampel}

Populasi merupakan semua objek yang akan diteliti.Populasi adalah wilayah generalisasi yang terdiri atas objek atau subjek yang mempunyai kualitas dan karakteristik tertentu yang ditetapkan oleh peneliti untuk dipelajari dan kemudian ditarik kesimpulannya (Sugiyono, 2011). Populasi yang digunakan dalam penelitian ini merupakan perusahaan sektor keuangan yang terdaftar dalam Bursa Efek Indonesia (BEI).

Menurut Sugiyono (2011) sampel adalah bagian dari jumlah dan karakteristik yang dimiliki oleh populasi. Sampel yang digunakan dalam penelitian ini merupakan perusahaan sektor keuangan dan masuk dalam index LQ45.

\section{Jenis Sumber Data}

Jenis data yang digunakan dalam penelitian ini adalah data sekunder.Data sekunder merupakan data yang diperoleh secara tidak langsung atau melalui perantara seperti diperoleh dari dokumen, hasil survey, hasil studi, data publikasi dari organisasi atau perusahaan, dan lain sebagainya. Data yang digunakan dalam penelitian ini adalah data harga saham penutupan harian (closing price) yang termasuk pada sektor keuangan dan masuk dalam kategori indeks LQ45 periode 2017 di BEI.

\section{Teknik Pengumpulan Data}

Pada teknik pengumpulan data terdapat banyak sekali teknik yang bisa dipakai. Dalam penelitian ini teknik pengumpulan data menggunakan teknik dokumentasi. Teknik dokumentasi adalah teknik dimana data yang ingin diteliti sudah tersedia melalui suatu laporan yang dikeluarkan suatu perusahaan atau instansi. Data yang diperoleh dalam penelitian ini berasal dari www.idx.co.id, (2019).

\section{Definisi Operasional \\ 1. Variabel Dependen}

Variabel dependen adalah variabel terikat, dimana variabel ini dipengaruhi variabel lain. Variabel yang terdapat pada penelitian ini adalah return saham harian dari sektor keuangan di Bursa Efek Indonesia (BEI) yang termasuk dalam indeks LQ45. Rumus yang digunakan adalah sebagai berikut:

Persamaan:

$$
R_{i t}=\frac{P_{i t}-P_{i t-1}}{P_{i t-1}}
$$

Keterangan :

Rit $=$ Return saham harian saham i pada hari ke t.

Pit $=$ Harga saham (closing price) harian saham i pada hari ke t.

Pit-1 = Harga saham (closing price) harian saham i pada hari ke $\mathrm{t}-1$.

\section{Variabel Independen}

Variabel independen adalah variabel bebas dan variabel ini mempengaruhi variabel lain. Variabel yang digunakan dalam penelitian ini adalah variabel dummy. Variabel dummy adalah variabel yang digunakan untuk mengkuantitatifkan variabel yang bersifat kualitatif (misal: jenis kelamin, ras, agama, perubahan kebijakan pemerintah, perbedaan situasi, dan lain-lain) (Sartika Putri, 2017). Variabel dummy dalam penelitian ini adalah the day of the week effect yang terdiridari lima hari perdagangan, yaitu Senin, Selasa, Rabu, Kamis, dan Jumat. Week-four effect yang terdiri dari Senin minggu pertama, Senin 
minggu kedua, Senin minggu ketiga, Senin minggu keempat, dan Senin minggu kelima. Rogalski effect yang terdiri hari Senin pada bulan april.

\section{Uji Instrumen}

a. Statistik Deskriptif

Statistik Deskriptif adalah statistik yang digunakan untuk menganalisa data dengan cara mendeskripsikan atau menggambarkan data yang telah terkumpul sebagaimana adanya tanpa membuat kesimpulan yang berlaku untuk umum atau generalisasi (Sugiyono, 2009).

b. Uji Normalitas

Uji normalitas bertujuan untuk membuktikan bahwa data yang dipergunakan berdistribusi normal. Model regresi yang baik adalah distribusi data normal atau mendekati normal (Thoifah, 2015). Uji normalitas menggunakan uji Jarque-Bera dengan menggunakan bantuan progam statistik. Dasar pengambilan keputusan jika probibalitas lebih besar atau sama dengan nilai alpha yang ditentukan, yaitu 5\%, maka data dikatakan berdistribusi normal, dan sebaliknya jika probibalitas kurang 5\% maka data berdistribusi tidak normal.

\section{Teknik Analisis Data}

\section{Uji Normalitas}

Uji normalitas berfungsi untuk melihat apakah variabel dependen danindependen terdistribusi normal atau tidak. Dalam penelitian ini uji normalitas menggunakan uji Kolmogorov-smirnov dengan menggunakan signifikansi 0,05. Hipotesis statistiknya dirumuskan sebagai berikut :

Ho : $=0$ (sampel berdistribusi normal)

$\mathrm{Ha}: \neq 0$ (sampel tidak berdistribusi normal)

Jika signifikansi lebih $>0,05$ maka data tersebut terditribusi normal. Jika signifikansi $<0,05$ maka data tersebut tidak terdistribusi normal sehingga pengujian dilakukan dengan metode statistik non parametrik.

\section{Descriptive statistic}

Pemaparan dari data peneliti yang dilihat dari nilai rata (mean), standar deviasi, nilai maksimum, dan nilai minimum. Descriptive statistic bertujuan untuk memberikan informasi dari data tersebut

\section{Kruskall Wallis Test}

Uji Kruskall Wallis Test. Uji ini bertujuan untuk menguji apakah nilai variabel tertentu berbeda pada dua atau lebih kelompok (Trihendradi, 2007). Hipotesis statistiknya adalah sebagai berikut :

$$
\text { Ho : } \mu_{S n}=\mu_{S l}=\mu_{R b}=\mu_{K m}=\mu_{J m}
$$

H1 : tidak semua ${ }^{\mu_{i}}$ sama

Dimana ${ }^{\mu_{i}}$ adalah rata-rata return hari ke i (senin, selasa, rabu, kamis, dan jumat).

Jika nilai signifikansi $>0,05$ maka Ho tidak dapat ditolak. Tapi jika nilai signifikansi < 0,05 maka Ho ditolak.

\section{Wilcoxon Test}

Wilcoxon test digunakan pada saat data diketahui tidak berdistribusi normal. Jika nilai signi. $>0,05$ maka Ho diterima. Tapi jika nilai signifikansi $<0.05$ maka Ho ditolak. Hipotses kedua menggunakan uji wilcoxon test sisi kiri. Hipotesis statistiknya adalah sebagai berikut :

Ho : $\mu_{\text {seninakhir }} \geq 0$

H2: $\mu_{\text {seninakhir }}<0$

Jika nilai sign. $/ 2>0,05$, maka Ho tidak dapat ditolak. Sedangkan jika nilai sign. $/ 2<0,05$, maka Ho diterima. Hipotesis ketiga menggunakan uji wilcoxon test sisi kanan. Hipotesis statistiknya sebagai berikut :

Ho $: \mu_{i}=\mu_{2}$

$\mathrm{H} 3: \mu_{i}>\mu_{2}$

Dimana adalah rata-rata return senin pada bulan april. Sedangkan adalah rata-rata return senin pada bulan selain april. Jika nilai sign. $/ 2>0,05$, maka Ho tidak dapat ditolak. Sedangkan jika nilaisign. $/ 2<0,05$, maka Ho diterima. 
HASIL PENELITIAN DAN PEMBAHASAN

\section{Hasil Penelitian}

Dari tabel 4.1 terlihat bahwa ratarata return terendah terjadi pada hari senin, dimana rata-rata return menunjukkan nilai 6570.73. Pada hari selasa terdapat kenaikan return yaitu sebesar 6572.94 disusul peningkatan return di hari rabu sebesar 6577.64. Pada hari kamis kenaikan terjadi cukup signifikan, dimana return meningkat sebesar 6601.99 dan pada akhir pekan tepatnya hari jumat kenaikan terus terjadi sebesar 6604.96.

Nilai standar deviasi terbesar terjadi di hari jumat, yaitu sebesar 5622.286. Hal ini diartikan bahwa hari jumat memiliki resiko tertinggi dibandingkan hari perdagangan lainnya. Sedangkan hari senin memiliki standar deviasi terendah, yaitu sebesar 5649.519, yang menandakan bahwa hari senin memiliki resiko paling kecil dibandinkan hari lainnya.

Nilai maksimum dan minimum menginformasikan bahwa return terendah selama periode penelitian terjadi pada hari selasa, yaitu sebesar 1699, sedangkan return tertinggi terjadi pada hari kamis, yaitu sebesar 21924.

\section{Uji Asumsi Klasik}

\section{A. Normalitas}

Menurut kusuma dan Ismanto (2012) Uji normalitas dilakukan untuk mengetahui apakah data yang kita olah normal atau tidak. Pada penelitian ini uji normalitas menggunakan uji Kolmogorovsmirnov. signifikansi lebih $>0,05$ maka data tersebut terditribusi normal. Dalam penelitian ini diketahui data normalitas adalah sebagai berikut:

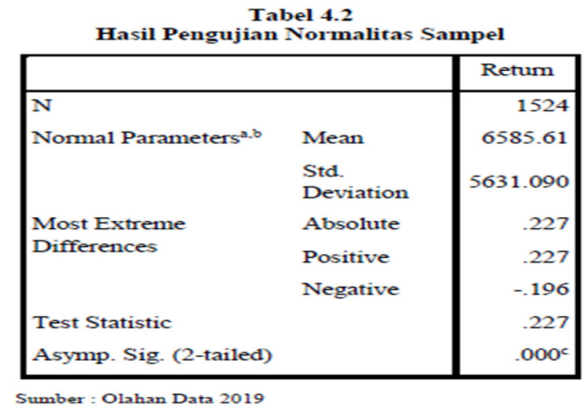

Setelah pengujian normalitas dilakukan, diketahui bahwa distribusi data sampel tersebut tidak normal, karena nilai sign. $0,00<0,05$ sehingga pengujian menggunakan metode statistik non parametrik.

\section{Uji Hipotesis}

1. Pengujian The Day of the Week Effect Pengujian ini menggunakan uji KruskallWallis test. Uji Kruskall-Wallis test merupakan uji non parametrik yang digunakan untuk menguji apakah terdapat suatu perbedaan yang signifikan antara kelompok variabel independen dengan variabel dependennya. Hasil pengujiannya adalah sebagai berikut:

Tabel 4.3

Hasil Pengujian Kruskall-Wallis

\begin{tabular}{|c|c|c|c|c|c|}
\hline & hari & $\mathrm{N}$ & $\begin{array}{l}\text { Mean } \\
\text { Rank }\end{array}$ & & Return \\
\hline $\begin{array}{l}\text { Retur } \\
n\end{array}$ & senin & 300 & 761.06 & $\begin{array}{l}\text { Chi- } \\
\text { Square }\end{array}$ & .036 \\
\hline & selasa & 306 & 760.43 & Df & 4 \\
\hline & rabu & 312 & 760.86 & $\begin{array}{l}\text { Asymp. } \\
\text { Sig. }\end{array}$ & 1.000 \\
\hline & kamis & 300 & 765.38 & & \\
\hline & jumat & 306 & 764.83 & & \\
\hline & Total & 1524 & & & \\
\hline
\end{tabular}

Berdasarkan hasil pengujian kruskall-wallis test dapat disimpulkan bahwa tidak terdapat perbedaan return saham yang signifikan selama 5 hari perdagangan. Hal ini dibuktikan dengan nilai sign. Sebesar 1,000 >0,05, maka Ho tidak dapat ditolak. Sehingga hipotesis dalam penelitian ini tidak dapat diterima. 


\section{Pengujian Week-Four Effect}

Pengujian hipotesis ini menggunakan wilcoxon test sisi kiri. Wilcoxon test merupakan uji komparatif 2 sampel bebas apabila skala data ordinal, interval atau rasio tetapi tidak berdistribusi normal. Hasil pengujiannya adalah sebagai berikut:

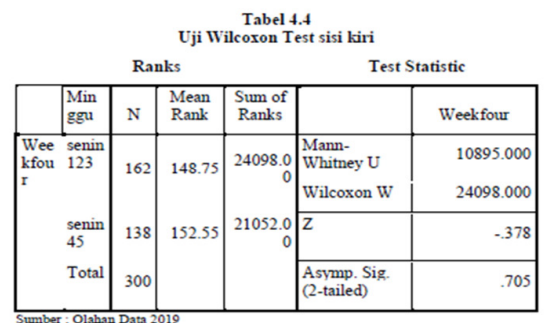

Berdasarkan tabel 4.4 diketahui bahwa nilai rata-rata return pada senin minggu 1-3 adalah sebesar 148.75. Sedangkan rata-rata return senin minggu ke 4-5 adalah sebesar 152.55. Dari hasil tersebut dapat diketahui bahwa rata-rata return saham adalah positif. Dengan nilai sig/2 untuk pengujian week-four effect sebesar 0,705. Dengan nilai alpha 0,05, maka didapatkan hasil $(0,705>0,05)$ yang artinya Ho diterima. Maka dengan hasil tersebut hipotesis yang diajukan tidak dapat diterima. Artinya return hari senin minggu 1-3 maupun minggu 4-5 adalah positif signifikan sehingga tidak terjadinya week four effect di perusahaan sektor keuangan yang ada di BEI periode 2017.

\section{Pembahasan}

\section{The Day Of The Week Effect}

Fenomena the day of the week effect pada perusahaan sektor keuangan yang ada di BEI tidak menyebabkan perbedaan return saham hari senin dengan hari lainnya.

Berdasarkan uji kruskall wallis test didapatkan bahwa nilai sign sebesar 1,000 $>0,05$, maka Hipotesis ditolak. Hal ini mengartikan bahwa tidak adanya perbedaan return yang signifikan pada hari senin dengan hari lainnya.

Hasil ini sejalan dengan penelitian yang dilakukan oleh Ambarwaty (2016) yang menghasilkan kesimpulan bahwa the day of the week effect tidak menimbulkan perbedaan return saham. Menurut Ambarwaty (2016), hal ini dikarenakan tidak bisa diprediksinya kapan investor akan melakukan pembelian dan penjualan saham. Hal ini yang menyebabkan ratarata return saham sama dikarenakan peningkatan supply yang diimbangi peningkata demand.

Berdasarkan hasil ini menunjukkan adanya ketidaksamaan dengan penelitian yang dilakukan oleh Rita (2009) yang membuktikan bahwa fenomena the day of the week effect terjadi di BEI, dimana return hari senilai lebih rendah dibandingkan rata-rata return hari lainnya.

\section{Week-Four Effect}

Fenomena week-four effect pada perusahaan sektor keuangan di BEI tidak menyebabkan perbedaan return pada senin minggu ke 1 , 2, dan 3 dengan senin minggu ke 4 dan 5. Berdasarkan hasil uji wilcoxon test menunjukkan bahwa nilai sig/2 sebesar 0,705 >0,05, maka Hipotesis tidak dapat diterima. Ini berarti week-four effect tidak menyebabkan perbedaan return pada senin minggu ke 1,2 dan 3 dengan senin minggu ke 4 dan 5 di perusahaan sektor keuangan di BEI atau bisa dikatakan return negatif tidak hanya terjadi pada minggu ke 4 dan 5 tetapi terjadi pada keseluruhan minggu.

Menurut Abraham dan Ikenberry (1994) dalm Rita (2009) menyatakan bahwa Monday effect berkaitan dengan perilaku perdagangan investor individual. Aktifitas perdagangan individu secara signifikan digerakkan oleh alasan likuiditas.Individu melakukan pembayaran bulanan mereka di akhir bulam dam individu cenderung membeli saham pada pergantian bulan serta melikuidasinya pada saat mendekati akhir bulan.alasan inilah yang menjelaskan terjadinya return pasar yang cenderung lebih rendah pada periode minggu ke 4 dan ke 5. Tetapi fenomena week-four effect tidak ditemukan pada penelitian ini. 
Menurut Rita (2009) hal ini terjadi dikarenakan tidak terdapatnya hubungan antara tuntutan masalah likuiditas dengan investasi di bursa, artinya danayang 36 diinvestasikan di bursa tidak digunakan untuk memenuhi tuntutan likuiditas setiap akhir bulan. Penelitian ini sejalan dengan penelitian yang dilakukan oleh Rita (2009) yang membuktikan bahwa return negatif dan signifikan terjadi pada keseluruhan minggu. Maryani (2017) juga mendapatkan hasil yang sama dimana Week Four Effect tidak menimbulkan perbedaan terhadap return saham.

Penelitian ini tidak sejalan dengan yang diteliti oleh Murtini (2007) yang menemukan adanya pengaruh yang sama dimana Return yang negatif hanya terkonsentrasi pada minggu kempat dan kelima.

\section{Rogalski Effect}

Rogalski effect merupakan suatu fenomena dimana return negatif pada hari senin menghilang pada bulan tertentu. Berdasarkan hasil pengujian peneliti, rogalski effect terjadi di perusahaan sektor keuangan di BEI. Hal ini ditunjukkan dengan nilai sign $/ 2(0,001 / 2)<0,05$, maka Hipotesis diterima. Hal ini membuktikan bahwa terjadi return positif dan cenderung lebih besar dibandingkan bulan lainnya pada hari senin di bulan April (Rogalski Effect).

Hal ini dikarenakan ketentuan yang ditetapkan oleh Badan Pengawas Pasar Modal No.80/PM/1996, yang menyatakan bahwa laporan tahunan harus

disertai dengan laporan akuntan dengan pendapat yang lazim dan disampaikan kepada Bapepam 120 hari setelah tanggal tahun tutup buku perusahaan. Sehingga pada bulan april kemungkinan Monday effect akan menghilang dan return pada bulan april cenderung lebih tinggi dari bulan lainnya.

Hal ini sejalan dengan penelitian Murtini (2007) dimana return hari senin bulan april adalah positif atau cenderung lebih tinggi dari return hari senin bulan lainnya. Hasil penelitian ini juga sejalan dengan penelitian Calryaningdyah (2005), dimana Rogalski effect ditemukan terjadi pada bulan April di BEI. Hal ini membuktikan bahwa penelitian yang dilakukan tidak sejalan dengan penelitian yang dilakukan oleh Putri (2014) bahwa tidak terdapat fenomena Rogalski effect pada perusahaan yang terdaftar sebagai indeks LQ-45 di BEI periode 2012-2013.

\section{KESIMPULAN DAN SARAN}

\section{Kesimpulan}

Berdasarkan analisis yang telah dilakukan maka dapat diambil beberapa kesimpulan sebagai berikut :

1. Tidak terjadi perbedaan return harian rata-rata dalam satu minggu pada return saham sektor keuangan di Bursa Efek Indonesia selama periode 2017.

2. Tidak terjadi return negatif pada senin minggu keempat dan kelima pada return saham sektor keuangan di Bursa Efek Indonesia.

3. Terjadi return positif dan cenderung lebih besar dibandingkan bulan lainnya pada hari senin di bulan April.

\section{Saran}

Berdasarkan penelitian yang telah dilakukan, saran yang bisa diberikan adalah sebagai berikut:

1. Investor

Penelitian ini mungkin dapat membantu para investor untuk menyusun strategi perdagangan investasi, memperhatikan waktu yang tepat dalam melakukan transaksi di Bursa Efek Indonesia.

2. Penelitian selanjutnya

a. Penelitian selanjutnya diharapkan menambah periode penelitian serta menguji variabel lain yang diduga mempengaruhi return saham.

b. Penelitian selanjutnya diharapkan menambah sampel yang akan diteliti. 


\section{DAFTAR PUSTAKA}

Cahyaningdyah, Dwi. 2005. Analisis Pengaruh Hari Perdagangan Terhadap Return Saham: Pengujian Week Four Effect, dan Rogalski Effect di Bursa Efek Jakarta. Jurnal Ekonomi dan Bisnis. Vol 20, No. 2.

Cahyaningdyah, Dwi, dan Rini Setyo Witiastuti. 2010. Analisis Monday Effect Dan Rogalski Effect Di Bursa Efek Jakarta. Jurnal Dinamika Manajemen Vol. 1, No. 2, 2010, Hal.154-168.

Fahmi, Irham, dan Yovi Lavianti Hadi. 2009. Teori Portofolio dan Analisis Investasi. Bandung: Alfabeta.

Gumanti, Tatang Ary. 2011. Manajemen Investasi Konsep, Teori dan Apllikasi. Jakarta : Mitra Wacana Media.

Hartono, Jogiyanto. 2003. Teori Portofolio dan Analisis Investasi edisi ketiga. Fakultas Ekonomika dan Bisnis UGM. Yogyakarta: BPFEYogyakarta.

Hartono, Jogiyanto. 2005. Pasar Efisien Secara Keputusan. Fakultas Ekonomika dan Bisnis UGM. Yogyakarta: PT Gramedia Pustaka Utama.

Hendi Fakhrudin dan Tjiptono Darmadji.2001. Pasar Modal Indonesia. Edisi pertama. Jakarta: Salemba Empat.

Iramani, Rr. dan Ansyori Mahdi. 2006. Studi Tentang Pengaruh Hari Perdagangan Terhadap Return Saham pada BEJ. Jurnal Akuntansi dan Keuangan.Vol. 8, No.2, Hal.6370 .

Jogiyanto, 2002. Teori Portofolio Dan Analisis Investasi Edisi Kedua.
Fakultas ekonomi UGM. Yogyakarta : BPFE-Yogyakarta.

Kristiawan, Agung. 2010. Analisis Return Jumat dan Return Senin Pada Indeks Likuiditas 45 di Bursa Efek Jakarta Jurnal Akuntansi. Manajemen Bisnis dan Sektor Publik (jambsp).Issn 1829 -9857 Jambsp Vol. 7, No. 1, Oktober 2010: $46-62$.

Lutfiaji. 2010. Pengujian The Day Of The Week Effect, Week Four Effect, Dan Rogalsky Effect Terhadap Return Saham LQ-45 Di Bursa Efek Indonesia.

Mulyono, sri. 2000. Peramalan bisnis dan ekonometrika. Yogyakarta: BPFEYogyakarta.41

Maryani, Widya Okta. 2017. Pengujian THE DAY OF THE WEEK EFFECT, WEEK FOUR EFFECT dan MONDAY EFFECT Terhadap RETURN

$\begin{array}{crr}\text { Saham Perusahaan } & \text { FOOD } & \text { AND } \\ \text { BEVERAGE di } & \text { Bursa } & \text { Efek } \\ \text { Indonesia Tahun 2014-2015. } & \end{array}$

Putri, Susetriani. 2014. Analisis MONDAY EFFECT Terhadap Return Saham di BEI Periode 20122013

Prayogo, Yun. 2009. Pengaruh Hari Perdagangan Terhadap Return Saham Perusahaan Yang Termasuk Di Jakarta Islamic Index. Skripsi. Yogyakarta: Universitas Negeri Sunan Kalijaga.

Sugiyono. 2011. Metode Penelitian Kuantitatif, Kualitatif dan R\&D. Bandung Alfabeta.

Tandelilin, Eduardus. 2001. Analisis Investasi dan Manajemen Portofoli.Ed. 1, Yogyakarta: BPFE. 
Tandelilin, Eduardus. 2010. Portofolio dan Investasi. Ed. 1, Yohyakarta: Kanisius.

Trihendradi, C. 2007. Langkah Mudah Menguasai Statistik Menggunakan SPSS 15 (Deskriptif, Parametrik, Non Parametrik): Andi Offset. Yogyakarta. ISBN: 978-979-290020-0.

Trisnadi, Margareta Maria dan Sedana, Ida Bagus Panji.2016.Pengujian Anomali Pasar : Day Of The Week Effect Pada Saham LQ-45 Di Bursa Efek Indonesia, Vol. 5, No. 6.

Usman, Marzuki dan Riphat Singgih. 1997. Pengetahuan Pasar Modal. Jakarta: Institute Bankir Indonesia.

Widodo, Purwanto. 2008. Studi Tentang Pengaruh Hari Perdagangan Terhadap Return Ihsg Periode Januari 1997 Sampai Dengan Mei 2008. National Conference On Management Research 2008. Makassar, 27 November 2008.

www.idx.co.id

www.yahoofinance.com 